\title{
REQUESTS FOR BINDING DECISIONS ON APPLICATION OF THE CODE
}

Edited by John McNeill \& John Wiersema

\section{(25) Request for a binding decision on whether Geisleria Nitschke (Ascomycota: Strigulaceae) and Geissleria Lange-Bert. \& Metzeltin (Bacillariophyceae: Naviculaceae) are sufficiently alike to be confused}

\author{
Saúl Blanco ${ }^{1}$ \& Carlos E. Wetzel ${ }^{2}$ \\ 1 Department of Biodiversity and Environmental Management, University of León, 24071 León, Spain \\ current address: Institute of the Environment, La Serna, 58, 24007 León, Spain \\ 2 Environmental Research and Innovation Department (ERIN), Luxembourg Institute of Science and Technology (LIST), \\ 41 rue du Brill, 4422 Belvaux, Luxembourg \\ Author for correspondence: Saúl Blanco, sblal@unileon.es
}

DOI http://dx.doi.org/10.12705/643.24

\section{Geisleria Nitschke (1861) [Fungi]}

Nitschke (in Rabenhorst, Lich. Europ. Exsicc. 21: 574. 1861) described the genus Geisleria with a single species, G. sychnogonioides Nitschke. The genus remained monotypic until 1954, when Servít (in Blumea 7: 594. 1954) published G. alpina Servít, and subsequently another three species have been proposed, although two of them (G. alpina and G. jamesii Swinscow) were transferred to more suitable genera, so that, apart from the generitype, only two more species are currently included in this genus, namely G. sbarbaronis Servít and G. xylophila Vězda, both known only from their types and not recently studied (Aproot \& al. in Lichenologist 46: 116. 2014). Proposals to synonymize Geisleria with Verrucaria Schrad. and Strigula Fr. have been criticized (Aproot \& al., l.c.). Ciferri \& Tomas (in Atti Ist. Bot. Univ. Lab. Crittog. Univ. Pavia, ser. 5, 10: 31, 59. 1953) erected the superfluous Geisleriomyces, based on the same type as Geisleria. The name Geisleria also denotes a genus of characoid fishes (Geisleria Gery in Vie \& Milieu, Sér. C, Biol. Terrestre 12: 154. 1971). The lichen genus was named after a Dr: Geisler, a senior physician in Münster, Germany who had an interest in lichens ("Die Gattung trägt den Namen des um die westfälische Lichenenkunde höchst verdienten Oberstabsarztes ["Oberstaabsarztes"] Hrn. Geisler zu Münster"). Noteworthy, the genus Geiseleria Klotzsch (in Arch. Naturgesch. (Berlin) 7: 254. 1841) in Euphorbiaceae has been misspelled as Geisleria many times in the botanical literature (e.g.; Schomburgk, Reis. Br.-Guiana 3: 1186. 1848; Sagra, Icon. Pl. Fl. Cub.: 42. 1863).

\section{Geissleria Lange-Bert. \& Metzeltin (1996) [Bacillarioph.]}

Geissleria Lange-Bert. \& Metzeltin (in Iconogr. Diatomol. 2: 63. 1996) was created to accommodate Navicula sect. Annulatae Hustedt sensu emend. at the rank of genus. The name commemorates the phycologist Dr. Ursula Geissler (Freie Universität, Berlin). After recent additions (Novais \& al. in Cryptog. Algol. 34: 117-148. 2013; Kulikovskiy \& al. in Phytotaxa 177: 249-260. 2014), this genus currently comprises 78 species distributed worldwide.

\section{Conclusion}

We are requesting a binding decision under Art. 53.5 of the $I C N$ (McNeill \& al. in Regnum Veg. 154. 2012) to determine whether Geisleria Nitschke and Geissleria Lange-Bert. \& Metzeltin are sufficiently alike to be confused and thus be treated as homonyms. Both names are taxonomically accepted and in current usage. In our opinion, the two names are sufficiently alike to cause confusion. In fact, both genera have been reciprocally misspelled in the literature (e.g.; Vagts \& al. in Aarhus Geosci. 4: 53-59. 1995; Kulikovskiy \& al., 1.c.). This parahomonymy is caused by the transliteration of the German letter " $\beta$ " ("eszett"), in eponyms originated from the common German surname "Geißler", in accordance with ICN Art. 60.4; indeed Nitschke on his manuscript label used the spelling "Geissleria" for the name that he published in print as Geisleria. If there is a decision to treat them as homonyms, an eventual conservation of Geissleria is warranted in order to preserve nomenclatural stability.

\section{Acknowledgments}

We are indebted to Drs. John McNeill and John Wiersema for their valuable comments. 